https://nv.nltu.edu.ua

https://doi.org/10.15421/40280723

ISSN 2519-2477 (online)

Article received $19.09 .2018 \mathrm{p}$.

Article accepted $26.09 .2018 \mathrm{p}$.

$@$ Correspondence author

удк 674.047:669.015.7.074(075.8)

I. М. Озарків, І. А. Соколовський, І. В. Петришак, М. С. Кобринович

Національний лісотехнічний університет Украӥни, м. Львів, Украӥна

\title{
РАЦІОНАЛЬНЕ ТЕПЛОВИКОРИСТАННЯ В СУЧАСНИХ СУШИЛЬНИХ КАМЕРАХ
}

Обгрунтовано деякі особливості раціонального тепловикористання в сучасних сушильних камерах, які часто використовують у промисловості та сільському господарстві. Об'єктом сушіння при цьому є як сировина - дошки, заготовки, паркетна фриза, так і напівфабрикати - лущений або струганий шпон, подрібнена деревина, а також готові вироби - фанера, стільці, крісла тощо. Проаналізовано процеси сушіння за кривими зміни середньої вологості матеріалу (об'єкта сушіння) в часі (так звані "криві сушіння") і зміни температури (криві), а також швидкості зміни вологості в часі. Встановлено, що висушування різних матеріалів за різних способів підведення до них тепла (конвекції, терморадіації, кондукції) під час постійних режимних параметрів складається із трьох періодів сушіння (періоду початкового прогрівання, періодів постійної та сповільнювальної швидкостей сушіння). Однак проблема зменшення енергетичних витрат на сушіння деревини залишається сталою, позаяк не здійснюється раціональне тепловикористання, а також мало використовуються сучасні способи та засоби інтенсифікації процесу сушіння деревини. Тому створення сучасного обладнання, що дає змогу вирішити цю проблему, - основна мета цієї роботи. Також розглянуто концепцію тепловикористання під час розроблення конструкцій сушильних камер для зменшення питомих витрат теплової енергії. Запропоновано деяку комбінацію методів визначення показників камери із складанням основних показників затрат теплової енергії, що витрачається на сушіння пиломатеріалів.

Ключові слова: камери сушіння; коефіцієнт корисної дії; регенерація; рекуперація; теплота; парокомпресори; конденсатор; волога пара; економічність теплового насосу; адіабата; тепловий насос; коефіцієнт трансформації тепла; потужність компресора; фреон; рекомпресія пари; теплові труби.

Вступ. Відомо, що процеси сушіння часто використовують у промисловості та сільському господарстві. Об'єктом сушіння при цьому можуть бути як сировина (дошки, заготовки, паркетна фриза), так і напівфабрикати (лущений або струганий шпон, подрібнена деревина), а також готові вироби (фанера, стільці, крісла, тощо).

Сушіння деревини - це дуже складний виробничий процес, що супроводжується протіканням ряду фізичних явищ:

- теплообміном матеріалу (об'єкта сушіння) із агентом сушіння (навколишнім середовищем);

• випаровуванням вологи (води) з поверхні матеріалу, що висушується, в навколишнє середовище;

- переміщенням тепла по матеріалу (теплопровідністю);

- поглибленням поверхні випаровування всередину об'єкта сушіння за рахунок вологоперенесення;

Процеси сушіння проаналізовано за кривими зміни середньої вологості матеріалу (об'єкта сушіння) в часі (так звані "криві сушіння") і зміни температури (криві), а також швидкості зміни вологості в часі. Встановлено, що сушіння різних матеріалів за різних способів підведення до них тепла (конвекції, терморадіації, кондукції) під час постійних режимних параметрів складається із трьох періодів сушіння (періоду початкового прогріван- ня, періодів постійної та сповільнювальної швидкостей сушіння). На сьогодні відомо різні способи раціонального тепловикористання, як і способи та засоби інтенсифікації процесу сушіння деревини. Однак проблема зменшення енергетичних витрат на сушіння деревини залишається. Тому основна мета нових розробок у цій роботі - це створення обладнання, що дає змогу вирішити цю проблему. Огляд питань, пов'язаних із енергетичною ефективністю сушильних камер, показав, що сьогодні існує достатньо способів і можливостей її підвищення. Розглянуто концепцію тепловикористання під час розроблення конструкцій сушильних камер для зменшення питомих витрат теплової енергії. Доцільна комбінація методів визначення показників камери із складанням основних показників затрат теплової енергії, що витрачається на сушіння пиломатеріалів. Частка статей балансу камери змінюється в досить широких межах залежно від типу і конструктивного виконання камер, режимів сушіння, характеристики пиломатеріалів тощо.

Виклад основного матеріалу. П. С. Серговський, I. В. Кречетовий, В. А. Баженовий, Г. С. Шубіний, П. Д. Лебедєв, В. А. Книш та інші автори сформулювали закони перенесення вологи для різних матеріалів.

\section{Інформація про авторів:}

Озарків Ігор Мирославович, д-р техн. наук, професор, кафедра технологій захисту навколишнього середовища і деревини, безпеки життєдіяльності та соціальних комунікацій. Email: bzd@nltu.edu.ua

Соколовський Ігор Андрійович, канд. техн. наук, доцент, кафедра ТЗНС і Д, БЖД та СК. Email: igorsokolov@ukr.net

Петришак Ігор Васильович, канд. техн. наук, доцент, кафедра ТЗНС і Д, БЖД та СК. Email: borason@ukr.net

Кобринович Михайло Стефанович, канд. техн. наук, доцент, кафедра фізики. Email: muchaylokobrynovuch@ukr.net

Цитування за ДСтУ: Озарків І. М., Соколовський І. А., Петришак І. В., Кобринович М. С. Раціональне тепловикористання в сучасних сушильних камерах. Науковий вісник НЛтУ України. 2018, т. 28, № 7. С. 104-108.

Citation APA: Ozarkiv, I. M., Sokolovskyy, I. A., Petryshak, I. V., \& Kobrynovuch, M. S. (2018). Rational use of heat in modern drying chambers. Scientific Bulletin of UNFU, 28(7), 104-108. https://doi.org/10.15421/40280723 
Науково-технічна проблема сушіння вологих матеріалів охоплює питання щодо перенесення тепла та маси (вологи) як всередині тіла (внутрішня задача), так і в пограничному шарі на межі розподілу фаз (зовнішня задача). Це означає, що результуюча інтенсивність сушіння залежить від умов перенесення тепла і маси як у середині тіла, так і на межі розподілу фаз "тіло - навколишнє середовище". Інтенсивність сушіння максимальна, коли можливості перенесення тепла і вологи в пограничному шарі відповідають можливостям переміщення маси і тепла в глибинних шарах об'єкта сушіння. Отже, загальне розв'язання задач процесу сушіння полягає саме в інтегруванні певної системи рівнянь перенесення тепла і маси як у самому матеріалі (об'єкті сушіння), так і в навколишньому середовищі.

Конвективний теплообмін $є$ одним із основних $\mathrm{i}$ найпоширеніших способів підведення теплоти до об'єкта сушіння.

Відомо (Ozarkiv et al., 2012; Koberle \& Trebula, 1981; Ozarkiv et al., 2014), що камерне сушіння пиломатеріалів $є$ найбільш енергомістким технологічним процесом. Встановлено, що коефіцієнт корисної дії лісосушильних камер становить $\eta=0,4 \ldots 0,5$. Це означає, що на випаровування вологи витрачається більше половини від загальної кількості теплової енергії, тобто

$$
\gamma_{\text {вun }}=1000 \frac{I_{2}-I_{0}}{d_{2}-d_{0}}-C_{6} \cdot t_{u},
$$

де: $I_{2}-$ ентальпія повітря під час виходу зі штабеля, кДж/кг; $I_{0}$ - ентальпія свіжого повітря (припливного), кДж/кг; $d_{2}, d_{0}-$ відповідно вологовміст повітря під час виходу зі штабеля і свіжого (припливного) повітря, г/кг сухого повітря.

Вологовміст $d_{2}$ визначають за формулою

$$
d_{2}=622 \cdot \frac{\rho_{n 2}}{100000-\rho_{n 2}} \frac{2}{\kappa 2 с у х . n о в},
$$

де $\rho_{\text {п2 }}$ - парціальний тиск водяної пари - визначається так:

$$
\rho_{\text {п2 }}=\varphi_{2} / \rho_{\mathrm{H}},
$$

де: $\varphi_{2}-$ відносна вологість повітря (ступінь насичення); $\rho_{\mathrm{H}}-$ тиск насичення, вибирають за Id-діаграмою або визначають за формулою Філенка Т. К., Пол.

Камерне сушіння має значні теплові втрати. Теплові втрати 3 потоками відпрацьованих теплоносіїв (підігрітого повітря) разом із висушеними пиломатеріалами, що вивантажують із камер, називають тепловими "відходами".

На сьогодні існують різні способи їхнього використання: регенерацією і рекуперацією теплоти відпрацьованих теплоносіїв. Для використання тепла відпрацьованих теплоносіїв необхідні спеціальні теплообмінні установки.

Регенерація тепла висушених пиломатеріалів можлива без спеціальних поверхонь нагрівання, тому що теплообмін здійснюється за безпосереднього контакту нагріваючого середовища (повітря) 3 охолоджувальним штабелем пиломатеріалів, що мають розвинену поверхню теплообміну.

У сучасних конвективних лісосушильних камерах повторне використання відпрацьованого агента сушіння відбувається завдяки тепловим насосам та рекуперативним апаратам (рекуператорам). Серед різних типів теплових насосів значного поширення в сушильних камерах набули парокомпресійні насоси.
У парокомпресійного насосу до випаровувача підводиться низькопотенційне тепло відпрацьованого вологого повітря, який охолоджується 3 одночасною конденсацією частини (частка) вологи. Завдяки цьому повітря, що виходить із випаровувача, осушується.

Внаслідок підведення теплоти холодильний агент теплового насосу випарюється за температури $t_{0}$ i тиску $p_{0}$. Утворююча суха насичена пара поступає в компреcop та стискується до тиску $p_{\kappa}$. Під час стискування повітря (холодильного агента) температура його підвищується до тиску $p_{k}$, а згодом пара переходить у стан перегрітої. Після стискування пара поступає в конденсатор, в якому охолоджується і конденсується за температури $t_{\kappa}$ i тиску $p_{\kappa}$, передаючи при цьому тепло осушуючому повітрю і нагріваючи його. Дальше рідкий робочий агент із конденсатора направляється у дросельний пристрій, в якому стискується тиск від $p_{\kappa}$ до $p_{0}$ під час одночасного зниження температури від $t_{\kappa}$ до $t_{0}$.

Парорідинна суміш (волога пара) робочого агента після дросельного пристрою поступає у випарювач і робочий цикл теплового насосу на цьому закінчується. За рахунок використання дійсної (явної) і прихованої теплоти, що сприйнята випарювачем, і тепла, еквівалентного роботі стискування компресором, здійснюється підвищення температурного потенціалу тепла від $t_{0}$ до $t_{\kappa}$.

Економічність теплового насосу визначають коефіцієнтом трансформації тепла $\mu$, який рівний відношенню кількості отримуваного в конденсаторі тепла $\left(\gamma_{\kappa}\right)$ до затраченої електричної енергії (роботи) компресором (1) за формулою

$$
\mu=\frac{t_{\kappa}}{t_{\kappa}-t_{0}}=\frac{1 / t_{0}}{1 / t_{0}-1 / t_{\kappa}} .
$$

Насправді, в циклі процес стискування в компресорі проходить в області перегрітої пари із внутрішніми втратами, внаслідок чого витрати енергії на стискування помітно збільшується і розраховується за формулою

$$
\lg =\frac{\mu_{a}}{\eta_{i} \cdot \eta_{e \imath}} \frac{\kappa Д ж}{\kappa 2},
$$

де: $\eta_{i} \approx 0,80$ - внутрішній (адіабатичний) к.к.д. компресора; $\eta_{\text {eл }} \approx 0,95$ - електромеханічний к.к.д. компресора.

Питому роботу компресора під час адіабатичного зворотного стискування визначаємо за формулою

$$
\ell_{a d}=\frac{K}{K-1} P_{0} \cdot \mathrm{Y}_{0} \cdot\left[\left(\frac{P_{\kappa}}{P_{0}}\right)^{\frac{k-1}{k}}-1\right] \frac{\kappa Д \varkappa}{\kappa 2},
$$

де: $K$ - показник адіабати; $\mathrm{Y}_{0}$ - питомий об'єм пари робочого агента на всмоктувальній старті компресора, $\mathrm{M}^{3} / \mathrm{\kappa}$.

Тоді коефіцієнт трансформації тепла для діючого циклу буде дорівнювати

$$
\mu_{\partial}=\frac{g_{\kappa}}{\ell_{\partial}}
$$

Завжди $\mu_{\partial}<\mu_{i}$.

Привід теплових насосів електричний. У цьому випадку використання теплових насосів енергетично доцільне лише тоді, коли вироблена в ньому теплова енергія, що віднесена до первинної енергії, відповідає виробленій в котельні. Умова реалізується за величини коефіцієнта трансформації тепла, рівного або більшого граничного значення, що визначаємо за формулою

$$
\mu_{\text {дгр }}=\eta_{\text {кот }} / \eta_{\text {кел }}-\eta_{\text {леп }},
$$


де: $\eta_{\text {кот }}-$ термічний к.к.д. котельні; $\eta_{\text {кел }}-$ енергетичний к.к.д. конденсаційної електростанції; $\eta_{\text {леп }}$ - енергетичний к.к.д. лінії електропередачі.

Для котельних лісопильних заводів $\eta_{\text {кот }} \approx 0,70 ; \eta_{\text {к ел }} \approx$

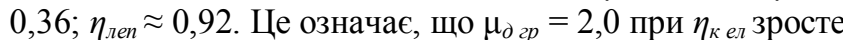
до 2,45 . Отже, із заокругленням у сторону запасу при значеннях $\mu_{\partial г p} \geq 2,50$ тепловий насос рівноекономічний за витратою палива $з$ котельнею.

Найкраще наведеним рекомендаціям відповідають сушильні камери періодичної дії із закритим циркуляційним контуром та низькотемпературними режимами сушіння (Koberle \& Trebula, 1981). На рис. 1 наведено значення коефіцієнта трансформації тепла для ідеального циклу Карно і реального конденсаційного теплового насосу залежно від температурної різниці $\left(t_{\kappa}-t_{0}\right)$ (Miuller, 1982).

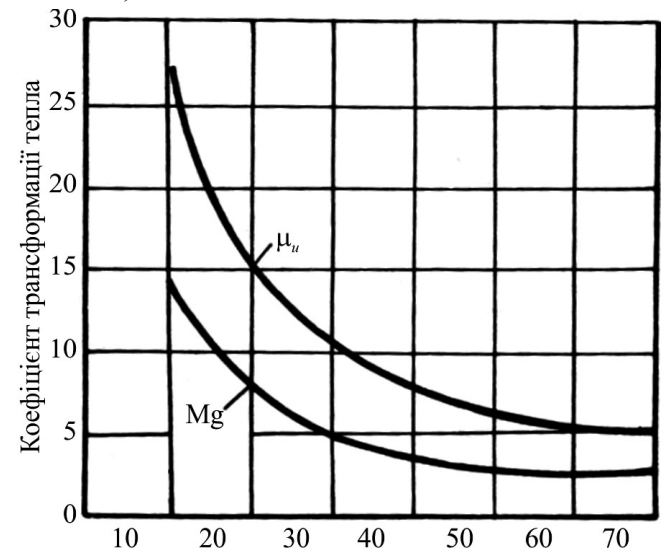

Рис. 1. Вплив різниці температур $\left(t_{\kappa}-t_{0}\right)$ конденсації і випаровування робочого агента та коефіцієнт трансформації тепла

Потужність компресора теплового насосу 3 електродвигуном, яка віднесена до клем електромотора, вираховуємо за формулою

$$
N=\frac{G \cdot h_{a}}{\eta_{i} \cdot \eta_{\text {eл }}}=G \cdot l_{\partial},
$$

де: $h_{a}$ - величина теплопередачі під час адіабатичного стискування; $G$ - витрати робочого агента.

Коефіцієнт корисної дії визначаємо за формулою

$$
\eta=\mu_{\partial} \cdot \frac{t_{\kappa}-t_{0}}{t_{\kappa}}
$$

На рис. 2 зображено схему камери з використанням теплових насосів (Aloiz, Spano, 1979).

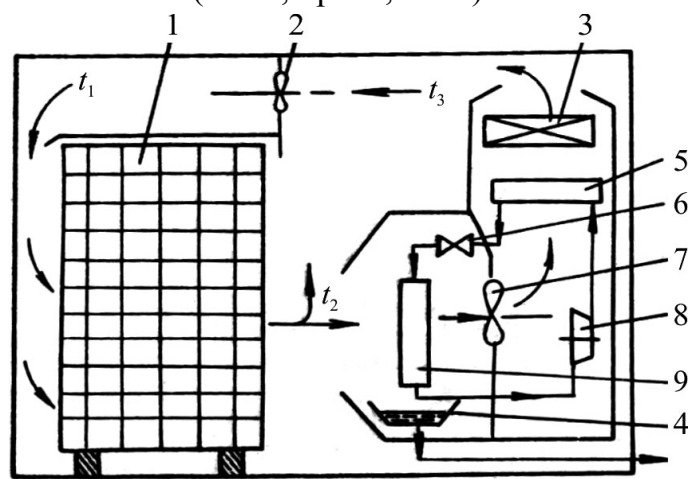

Рис. 2. Сушильна камера з тепловим насосом: 1) штабель пиломатеріалів; 2) осьовий вентилятор; 3) калорифер; 4) дренаж; 5) конденсатор; 6) дросельний клапан; 7) вентилятор теплового насосу; 8) компресор; 9) випарювач

Частина відпрацьованого сушильного агента 3 температурою $t_{2}$ направляється вентилятором теплового насосу у випарювач, в якому він охолоджується і зневод- нюється завдяки конденсації водяної пари. Потім повітря нагрівається в конденсаторі теплом, що сприймається випалювачем, і теплом, еквівалентним роботі, затраченій на привід компресора. Перед надходженням у сушильну камеру повітря додатково нагрівається в калорифері до температури $t_{3}$ і змішується з основним потоком рециркулюючого агента сушіння температурою $t_{2}$. Внаслідок утворюється вихідний сушильний агент із температурою $t_{1}$, який 3 допомогою вентилятора подається у штабель пиломатеріалів.

Електричний мотор вентиляторів і компресора розташовується в камері й охолоджується агентом сушіння, що покращує використання тепла. Такі сушильні камери 3 конденсацією вологи в тепловому насосі називають конденсаційними і в них можливе повне використання агента сушіння.

Повітрообмін через вентиляційну систему з навколишнім середовищем відсутній. Це означає, що відсутні втрати тепла, що викликаються ним. Сдиними тепловими "відходами" $є$ тепло конденсату.

Розрахунки показують, що в конденсаційних сушильних камерах із використанням теплових насосів питоме споживання тепла можна знизити на 20-30\%. Істотний вплив на теплову потужність теплового насоса має використовувальний робочий агент (найчастіше використовують фреон).

Розкладання фреону здійснюється за температури $120-130{ }^{\circ} \mathrm{C}$, а значення теоретичного коефіцієнта трансформації тепла $\mu_{\mathrm{i}}=4,8^{ \pm 10} \%$. Найпоширенішими є фреони Ф-12, Ф-22, Ф-113, Ф-114.

Максимальна температура сушильного агента під час використання зазначених вище робочих агентів обмежується температурами 50-60 ㄷ. На фірмі "Валмет" у низькотемпературних сушильних камерах періодичної дії використовують теплові насоси із застосуванням фреону Ф-114 (рис. 3).

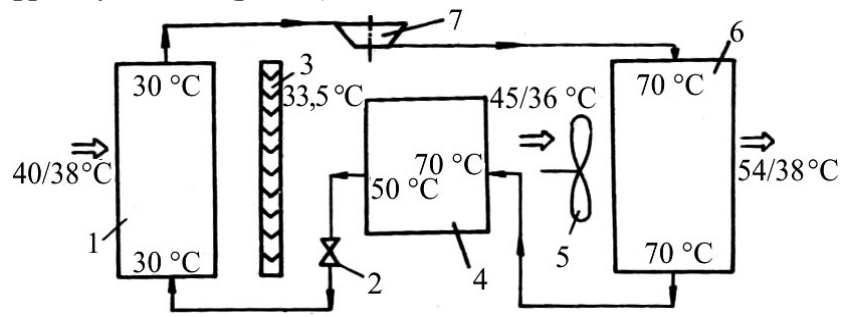

Рис. 3. Одноконтурний тепловий насос "Валмет": 1) випарювач; 2) дросельний клапан; 3) каплевідділювач; 4) переохолоджувач; 5) вентилятор; 6) конденсатор; 7) компресор

Характерною особливістю схеми є розміщення за конденсатором переохолоджувача рідкого фреону, що збільшує кількість тепла, яке підводиться до сушильного агента. У тепловому насосі використовують гвинтовий компресор, а випарювач, конденсатор і переохолоджувач виготовлено 3 мідних труб із алюмінієвими пластинчатими ребрами. Регулювання потужності теплового насосу здійснюється за рахунок зміни продуктивності компресора.

На рис. 4 і 5 зображено схеми компонування рекуператорів на базі теплових труб і проміжковим теплоносієм у сушильних камерах періодичної дії фірми "Хільдебранд". Теплові труби забезпечують швидкісне сприйняття тепла від відпрацьованого агента сушіння і перенесення до свіжого повітря. Їх можна використовувати для камер із невеликим повітрообміном. Обидві ці схе- 
ми рекуперації дають змогу повернути в сушильну камеру із свіжим повітрям до 50 \% теплової енергії, що міститься у видаляючому відпрацьованому агенті сушіння.

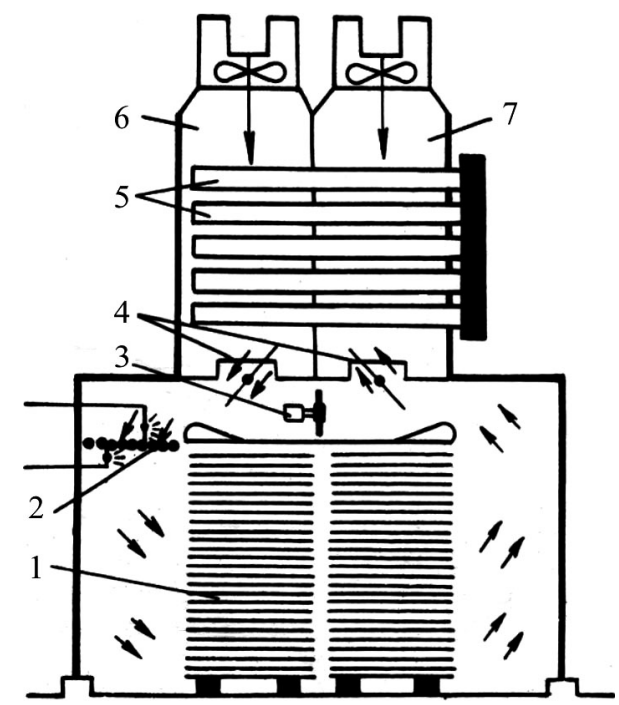

Рис. 4. Схема рекуператора в камерах фірми "Хільдебранд": 1) штабель; 2) компресор; 3) вентилятор; 4) шибери; 5) теплові труби; 6, 7) припливний і витяжний канали

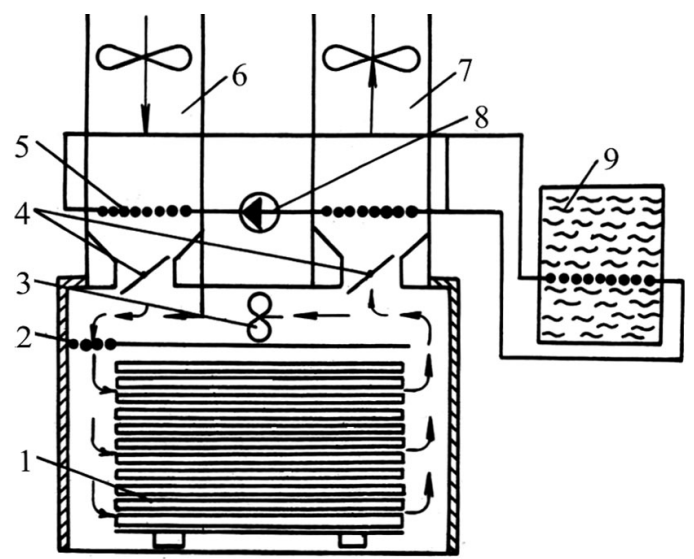

Рис. 5. Схема рекуператора в камерах "Хільдебранд" із проміжковим теплоносієм: 1) штабель; 2) калорифер; 3) вентилятор; 4) шибери; 5) теплообмінники рекуператора; 6, 7) припливний i витяжний канали; 8) насос; 9) додатковий нагрівач води для підсобкових потреб

Сушильна камера з рекомпресією пари (див. рис. 4) складається із герметичної камери 3 вентиляторами для циркуляції агента сушіння і паровими калориферами. Для видалення утвореного конденсату, що осідає на стінах камери та інших елементах, встановлюють дренажні труби, що мають клапани, які запобігають втіканню пари. Сушильна камера має вихлопні отвори для видалення повітря, яке $\epsilon$ в камері на початку сушильного процесу. Компресор всмоктує пару з нижньої частини камери, що забезпечує стискування менш перегрітої пари і зменшує витрати енергії компресором.

\section{И. М. Озаркив, И. А. Соколовский, И. В. Петришак, М. С. Кобринович \\ Национальный лесотехнический университет Украины, г. Львов, Украина}

\section{РАЦИОНАЛЬНОЕ ТЕПЛОИСПОЛЬЗОВАНИЕ В СОВРЕМЕННЫХ СУШИЛЬНЫХ КАМЕРАХ}

Рассмотрена концепция использования при разработке конструкций сушильных камер с целью повышения удельных расходов тепловой энергии. Известно, что процессы сушки широко используются в промышленности та сельском хозяйстве. Объектом сушки при этом может быть как сырье (доски, заготовки, паркетная фреза), так и полуфабрикаты (лущенный или струганный шпон, измельченная древесина, а также готовые изделия (фанера, стулья и т.п). Процессы сушки проанализированы по кривым изменения средней влажности материала во времени (так называемые "кривые сушки") и изменения 
температуры (кривые), а также скорости изменения влажности во времени. Целесообразна комбинация методов определения показателей камеры с использованием составления основных показателей расходов тепловой энергии, что идет на сушку пиломатериалов. Величина статей баланса сушильной камеры изменяется в широких пределах в зависимости от тепла и конструктивного исполнения камер, режимов сушки, характеристики пиломатериалов и т.п.

Ключевые слова: сушильные камеры; коэффициент полезного действия; регенерация; рекуперация; теплота; парокомпрессоры; конденсатор; пара; адиабата; тепловой насос; коэффициент трансформации тепла; мощность компрессора; фреон; рекомпрессия пары; тепловые трубы.

\section{M. Ozarkiv, I. A. Sokolovskyy, I. V. Petryshak, M. S. Kobrynovuch}

Ukrainian National Forestry University, Lviv, Ukraine

\section{RATIONAL USE OF HEAT IN MODERN DRYING CHAMBERS}

Drying processes are known to be widely used in industry and agriculture. The object of drying can be either raw materials such as boards, workpieces, and parquet frieze or semi-finished products (peeled or planed veneer and chopped wood), as well as finished products (plywood, chairs, armchairs, etc.). Wood drying is quite a complex manufacturing process accompanied by a number of physical phenomena such as heat exchange of the material (object of drying) with the drying agent (environment), moisture evaporation (water) from the surface of the dried material to the environment, heat transfer throughout the material (thermal conductivity), deepening of the surface of evaporation inside the object of drying due to moisture transfer. Drying processes are analyzed according to the curves of the change of the average humidity of the material (the object of drying) over time (so-called "drying curves") and temperature changes (curves), as well as the rate of change in moisture content in time. The authors have established that drying of various materials applying various methods of heat transfer (convection, thermal radiation, conduction) under constant regime parameters consists of three drying periods such as the period of initial warming, periods of constant and falling drying rates. Various methods of rational use of heat, as well as methods and means of intensifying the wood drying process are known nowadays, although the problem of reducing the energy costs of wood drying remains. Therefore, the main purpose of new developments in this work is the creation of equipment that can solve this problem. The review of issues related to the energy efficiency of drying chambers has shown that there exist enough ways and opportunities of its increasing. The concept of rational use of heat designing of drying chamber in order to reduce specific heat consumption costs is considered in this paper. It is reasonable to combine the methods for determining camera performance with the compilation of the main indicators of the cost of heat energy, going to drying lumber. The proportion of the chamber's parts balance varies substantially, depending on the type and design of the chamber, drying modes, lumber characteristics etc.

Keywords: drying chamber; coefficient of performance; regeneration; recuperation; heat; steam compressors; condenser; wet steam; heat pump efficiency; adiabatic; heat pump; heat transformation coefficient; compressor power; freon; steam recombination, heat pipes. 